YEVHENIA FEDOROVA

Senior inspector of postgraduate courses department Khmelnytskyi National University, MES of Ukraine Address: 11 Instytutska Str., Khmelnytskyi, 29016, Ukraine E-mail: fedorova-e@ukr.net

\title{
CULTIVATION OF SPECIAL NEEDS STUDENTS' CITIZENSHIP AS THE BASIS IN THE ASPIRATION OF UKRAINE TO EUROPEAN INTEGRATION
}

\begin{abstract}
The prospects for the cultivation of special needs students' citizenship as a prerequisite for the entry of Ukraine into the European Community have been described. The priority of compliance of European democratic sociocultural standards and humanistic values, among which the most important are the changes of attitude towards the disabled people, providing the establishment of equal rights for all Ukrainian citizens, has been specified. It has been confirmed that equal rights for all citizens are a guarantee of the disabled person's civil self-affirmation and preservation of his honor and dignity. An analysis of domestic and foreign scholars' works on the issue of citizenship education of young people with special needs has been represented. The pecularities of the special needs students' citizenship education in the integrated environment of higher educational institutions have been characterised. On the basis of the analyzed literature it has been determined that a special needs' student has got an opportunity to gain greater understanding of himself and his role in the society, improve his adaptive skills, expand the range of interests and social circle, ensure his own potentialities as a social unit and assert himself in his own value to the society under the conditions of higher educational institution of integrated type. The factors underlying the formation of special needs students' citizenship in the integrated environment of higher educational institution and characterizing the individual's citizenship in the democratic society have been thoroughly described.

Key words: citizenship, special needs students, integrated environment, higher educational institution of integrated type.

\section{INTRODUCTION}

The Revolution of dignity started at the end of 2013 in Kiev irreversibly changed the consciousness of the Ukrainians and their attitude towards themselves as to citizens of Ukraine as well as the attitude of the world community to our nation. The people of Ukraine at the expense of their lives have proven the ability to defend their dignity and freedom of choice to the last and to protect the democratic values and the independence of their country, the only Homeland. The protest moods spread throughout Ukraine. Thing that started as a peaceful action of students against the disrupt of signing the Association Agreement with $E U$, turned into a fierce confrontation between the citizens and the authoritarian state system. The representatives of various social groups of Ukraine - students, intellectuals, pensioners, workers and peasants - equally devotedly jointed to this struggle.

At this time the peculiarity of the Ukrainian protests was that the revolutionary processes were actively supported by special needs people. The special needs citizens turned from passive observers into active participants of the events on the Independence Square in Kiev.
\end{abstract}


Young people with special needs declared equal rights of citizens regardless of physical disabilities and side-by-side defended their positions on the main square of the state. Public activity of Ukrainian special needs students confirms the presence of patriotic aspiration, but its effectiveness and efficiency requires new forms and methods of citizenship upbringing.

THE AIM OF THE STUDY

The purpose of the article is to reveal the perspectives of cultivating citizenship of students with special needs as a prerequisite to the entry of Ukraine into the European Community.

\section{THEORETICAL FRAMEWORK AND RESEARCH METHODS}

The theoretical basis of the study represents modern contributions of researchers to the mentioned problems. The problems of psychophysical development of special needs people, methods of their training, education, rehabilitation and socialization are investigated by modern Ukrainian scientists such as O. Bezpalko, V. Bondar, M. Chaykovskyi, A. Kapska, O. Karpenko, O. Pol'ovyk, P. Talanchuk, V. Tserklevych, I. Yeremenko, N. Zasenko.

Some aspects of learning support of students with disabilities in higher educational institutions are discussed in the papers of O. Bazhan, K. Kolchenko, D. Konoplitska, H. Nikulina, P. Talanchuk, A. Shevtsov, V. Shyyan and others. Pecularities of teachers' work in the integrated student groups, where special needs students are taught, were studied by K. Kolchenko, N. Kozlikovska, H. Mazarska, Sh. Raver-Lampan and other. L. Voloshko investigated the usage of group education activities for special needs students as a part of small academic groups and as a factor of their self-esteem formation.

Most of these research works deal with the problems of special education; give scientific rationale of the system and content of education and training in special educational institutions; define the methodology of remedial training and education of people with disabilities, their medical and psycho-pedagogical support; search effective methods and means of correction and educational work.

\section{RESULTS}

The problem of special needs citizens' social integration is one of the priorities of Ukrainian national system of education on the way to the establishment of effective democratic regime and is the key for the creation of active and highly developed civil society, as today there are 2,6 million people with disabilities in our country, and it makes $5,5 \%$ of the total population. So, every eighteenth our compatriot has a disability, and is the person who needs some help and support from the state, not only in the monetary form but also in special house planning, outfitting of staircases and public transport, provision with certain facilities and products, assistance in getting education, professional skills, employment, medical and cultural services.

Until recently the notion of "invalid" (from the Latin "Invalidus" - weak, feeble) was widely used within the conceptual framework of educational research. According to the Declaration on the Rights of People with Disabilities (UN, 1975) a disabled person is any person unable to ensure by herself or himself, wholly or partly, the necessities of a normal individual and/or social life, as a result of deficiency, either congenital or not, in his or her physical or mental capabilities. Considering this we suppose that the notion "disabled person" should not be attributed only to the subject of life, but also be observed as a social phenomenon, namely as the interaction of psychophysical limitations and barriers of social character.

According to Article 2 of the Law of Ukraine "On the Principles of Social Protection of the Disabled in Ukraine" a disabled person is a person with a stable body dysfunction, caused by the disease, trauma or congenital defects, leading to disability and the need for social assistance and protection (Закон України «Про основи соціальної захищеності інвалідів в Україні», 1991). 
These terms reflect the medical model, which "considers health problem as a person's characteristics that may be caused by illness, trauma or health condition" and, therefore, requires medical or other intervention to "correct" the problem. Naturally, the reaction of a society in the context of justifying the medical model is providing the treatment, rehabilitation and social care, such as special education and pension. In other words, the goal is to make life of a special needs' person to some extent "normal", for example to ensure his economic and educational opportunities.

An attempt to analyze the concepts used by social and rehabilitation pedagogy was made in the thesis of M. Chaikovskyi. The author noted that the term "special needs people" is not stable. Generally, people with functional limitation (disabled) are qualified in most cases in this way. A. Kapska, S. Palchevskyi give different definitions to this category of people: "handicapped", "challenged people", "disabled children", "special needs people", "people with functional limitation", "people with disabilities", "people with limited mobility" and etc.

We share the position of $\mathrm{P}$. Talanchuk who proposes to adhere to the term "special needs people" while qualifying people with functional limitation (disabled) and to avoide psychologicaly destructive term "disabled" (Стандартные правила обеспечения равных возможностей для инвалидов, 2002). It traumatizes the psyche of young people less, boosts self-confidence, furthers social integration and adaptation to the conditions of new environment. This position is shared by M Chaikovskyi, who considers the term "special needs people" to be the most appropriate under the circumstances (Таланчук, Кольченко \& Нікуліна, 2004).

"References 1185 " to the rehabilitation programs of the $44^{\text {th }}$ session of the Parliamentary Assembly of the Council of Europe, dated May 5, 1992, are worth respect. In these documents the disability is defined as limitation in capability caused by physical, psychological, sensory, social, cultural, legal and other barriers, that don't allow a disabled person to be integrated into society and participate in family or social life on the same basis as other members of society.

Following the analysis of legal documents and scientific papers of domestic and foreign scholars and also educational practice we have made the conclusion that people with different kinds of lapses, but no contraindications for studying are referred to the special needs students. In particular, these are people who have speech abnormality with normal hearing ability and preserved intellect; hearing disorder (deaf or partially deaf); vision disorders (blind or partially blinded); locomotor apparatus disorders; sensory, emotional-volitional, physical and other disabilities, as well as physical disabilities that prevent from studying in a normal educational institution.

"Standard Rules on the Equalization of Opportunities for Disabled People" approved by the forty-eighth session of UN General Assembly, on December 20, 1993 were developed for the defense of special needs people's rights who, due to the disability and incapacity for work, face with difficulties and barriers for participation in life of the society. The document stresses that countries must use all means to provide each individual with equal opportunity for participation in the life of the society. After getting equal rights the disabled should also get equal obligations. The society can expect more from the disabled after they get equal rights. While providing equal opportunities it is necessary to create conditions to assist disabled people and to enable them to fulfill their responsibilities as full members of the society. The sixth rule states that countries should recognize the principle of equal opportunities in primary, secondary and higher education for special needs children, youth and adults in integrated structures, in order to transfer education into an integral part of general education for disabled people (Леонгард, 1998). 
Our state should provide special needs people, according to their desires and interests, with affordable and free education in state and communal educational institutions on the level that meets the individual skills and abilities according to the Constitution of Ukraine (Конституція України, 1996). The Order of Ministry of Education and Science, Youth and Sports of Ukraine № 512 dated April 24, 2012 "On conducting the experiment on organization of integrated education for people with special educational needs in higher educational institutions of I-IV levels of accreditation, regardless of the form of ownership and subordination" was issued in execution of the constitutional provision.

As shown in the national educational practice, training and education of integrated type remain top-priority in ensuring equal opportunities for the development of students with mental disabilities during their fromation as individuals and citizens of Ukraine considering their specificity.

An outstanding special education teacher L. Vyhotskyi in his works gave the highest importance to education as means of integrating people with functional limitations in social relations. The scientist noticed that the anomaly inevitably generates the desire for compensation and overcompensation, regardless of the individual's intellectual development level. Accordingly, the process of compensation will have both conscious and unconscious nature, and the most effective development of the person will take place under the presence of sociocultural environment (Выготский, 1983). L. Vyhotskyi has developed the idea of integrated education as a pedagogical system that combines special and general education aimed at creation of the conditions for overcoming social consequences of biological defects of the development ("social dislocations").

E. Leonhard formulated the integration of people with disabilities as "free, natural state and behavior of peole that are aware of their difficulties; initiative in communication; ability to solve their own problems; respect for others; and willingness to give and accept the assistance" (Концепція національного виховання, 1996).

V. Hudonis reveals integration of people with functional limitations in his scientific exploration as "a system of education, in which, on the one hand, a blind man is involved, and on the other - a society that assess and understand him adequately as an equal partner and a member of human society" (Гудонис, 1998).

Such training and education provides the inclusion of special needs students not only in the educational environment, but also in extracurricular activities. Social integration of special needs students hapens by means of common leisure and participation in various events, forming in such way an integrated educational environment on the basis of co-existence, co-creation principles, focusing on overcoming of social exclusion. The ideas of I. Ivanova, K. Kolchenko and P. Talanchuk, who consider such association as promotion of humanistic education of students and socialization of special needs students, deserve respect (Стандартные правила обеспечения равных возможностей для инвалидов, 2002). Because of the defined specific features of special needs students the integrated environment under the conditions of appropriate pedagogical tools can be a creating factor of total acceptance atmosphere, mutual recognition and respect. Young people with disabilities in the integrated environment have a chance to show their achievements, the ability to demonstrate the result of work, eliminate shyness to express their own point of view, to develop communicativeness.

In the context of our research it is reasonably to promote personal dignity and respect to all subjects of the educational process; to cultivate the need for adherence of moral norms and principles of public life, respect for the laws of Ukraine; to develop the ability to defend one's rights and freedoms, collaborate in a team, demonstrate initiative, creativity, tolerance to others, ability to find a compromise and responsibility in the integrated 
environment. In addition, it is important to activate the ability to demonstrate reflection, self-control, self-improvement of civil and moral qualities - the determinant components of citizenship. Under such circumstances, a special needs citizen is acting not as an object of social, educational, psychological and medical assistance and care, but as an active subject of Ukrainian civil society, what creates conditions for his successful establishment as a citizen and patriot with formed civic-mindedness.

The developers of the Concept of children and youth education in the national system of education of Ukraine stressed that "a highly educated, professionally competent, resourceful personality, endowed with deep national consciousness and statist responsibility, healthy intellectual and creative, corporeal, spiritual and moral, aesthetic, family and patriotic feelings is the ideal of education at present” (Закон України «Про освіту», 1991).

The existence of special needs complicates the socialization process, encourages people with disabilities to allocate among the diversity of social values those that can assist them in overcoming life and social barriers. The civic consciousness is such social and moral value.

The updating of this issue reinforces the need for society humanization. The democratic state's community aims to fulfill its humanitarian duty to the young citizens with special needs. Thus, there is a clear need to attract young people with disabilities to participate in public activities, capable to help them in their development as active and equal rights citizens of Ukraine. However, it is extremely important to establish civic and patriotic values of this group of people for the implementation of this task.

The main feature of modern students in psychological sources, describing them as an age group, is that they are insufficiently stable in psychological condition, labile emotionally and, therefore, sensitive to external influences. Therefore, special needs students are very sensitive to everything that goes around them and personally with them. A special needs student as a person is observed from three positions: psychological, social and biological. Traits of character, communication skills, self-esteem and self-perception, that are the psychological features of a student, are taken into consideration while psychological examination. Socially a student is observed as a representative of social group of people with disabilities. The biological side is predetermined by physical disabilities and special needs related with them.

Such prominent scientists as I. Bekh and I. Zyazyun gave this problem a ranking place in their works. They raised the issue of the ratio of biological and social in a person, and consideration of this aspect in the educational process (Бex, 1991). This problem becomes important in the process of special needs student's citizenship education, because the main tasks of the educational work with them is taking into account their capabilities, abilities and inclinations.

Special needs students have certain problems that have formed in the previous periods of their life and studying and significantly affect their cognitive activity and integration into the educational environment. Among them are: gaps in knowledge, difficulties in overcoming barriers of the environment, in particular education; difficulties in education material perception in the common way; lower working ability, increased fatigue, disoder of attention focusing; increased vulnerability to infectious diseases and because of it the problems with school attendance; low level of physical conditioning; shortage of sociability; lack of orientation in the society, low social activity; getting used to undemanding and condescending attitude, overstated idea of their capabilities; low motivation to goal achieving, a sense of future loss; low level of self-actualization, indecision, prevalence of introverted behavior; low self-esteem, self-control underdevelopment; increased anxiety, vulnerability, emotional instability, depressive positions and many others (Стандартные правила обеспечения равных возможностей для инвалидов, 2002). 
The seriousness of the situation for special needs students is reinforced by the fact that almost all of them feel the lack of communication with peers, physical discomfort, and lack of preparation for total flow of media's negative impact. Social moods of pessimism, disappointment in their own abilities and capabilities to fulfill themselves, loss of trust to other citizens and to the state are common among this part of young people. The existing social values don't fully express the defined needs of a particular social group. Learning of patriotic and humane values, national and cultural experience of the state, the aspiration to the rule of law and its simulation in their own life are general principles of all students, in our opinion. Modern civilization brings human values to the forefront, considering human rights and dignity, humanity, freedom of choice and tolerance to be the most important component parts (Чайковський, 2006).

Citizens' rights and dignity are not only his personal property, but also "gold pool" of society, nation and Ukraine that are protected by the fundamental law of the state - the Constitution. In order to awaken civic-mindedness among young people with special needs, it is necessary firstly to arouse self-respect and dignity, to remind them of equal rights and responsibilities and the entire constitutional equivalence of all citizens of Ukraine. The formation of these democratic values is an important component of education of special needs students. Such students should be educated as decent and concerned citizens and patriots with established civic-mindedness, as individuals who have absolute right for implementation of their own abilities, right to happiness, love and individuality.

\section{CONCLUSIONS}

Comprehensive analysis of contemporary researchers' scientific works allows to conclude that special needs student has got an opportunity to gain a greater understanding of himself and his role in the society, to improve his adaptive skills, to expand the range of interests and social circle, to ensure in his own potentialities as a social unit, to assert himself in his own value to the society under the conditions of higher educational institutions of integrated type.That particular things create the basis for citizenship formation, arousing interest of students in acquiring citizenship basics, cultivation of value components and realization of acquired knowledge and skills in their own life. A special needs student has to aquire a complex of civil functions namely under the conditions of higher educational institutions of integrated type. The cultivation of a person's citizenship is the basis for Ukrainian efforts to European integration. Modern European Community with perfect modern socio-cultural standards and humanistic values can satisfy our efforts only under certain conditions, the top priority among which are changes in attitudes toward the disabled, providing the establishment of equal rights for all people. They are a guarantee for a special needs person's civil self-esteem and for preserving his honor and dignity.

European community, thanks to the revolution, has realized that courageous, freedomloving, irresistible people willing to live, work and make even greater efforts for better future in their Homeland live in the "heart" of Europe. Ukrainians in wheelchairs on the Maidan are the smallest fraction of things that special needs citizens are able to do. They need only meaningful directing measures. The newest pages in the history of independent Ukraine are written with blood of "Nebesna sotnia" ("Heavenly Hundred"). And we all want to hope that these victims were not unavailing. SLAVA UKRAINI! HEROYAM SLAVA! (GLORY TO UKRAINE! PRAISE TO THE HEROES!)

\section{REFERENCES}

1. Бех, І. (1991). Моральність особистості: стратегія становлення [Person's morality: the development strategy]. Київ: УЗМН (in Ukrainian). 
2. Выготский, Л. (1983). Основы дефектологии [Basics of defectology]. In: Выготский, Л. (ed.) Принципь воспитания физически дефективних детей [Principles of educating physically handicapped children]. Москва: Педагогика, с. 34-49 (in Russian).

3. Гудонис, В. (1998). Основы и перспективы социальной адаптации лиц с пониженням зрением [Basics and prospects of social reintegration of people with poor eyesight]. Москва: Воронеж (in Russian).

4. Верховна рада України [The Verkhovna Rada of Ukraine]. (1991). Закон України "Про основи соичальної захищеності інвалідів в Украӥні" від 21.03.91 [Law of Ukraine On the Principles of Social Protection of the Disabled in Ukraine, dated 21.03.91]. Київ: Офіційне видання Верховної Ради України, с. 252 (in Ukrainian).

5. Верховна Рада України [The Verkhovna Rada of Ukraine]. (1996). Конституиіiя України [The Constitution of Ukraine]. Київ: Офіційне видання Верховної Ради України, c. 92-99 (in Ukrainian).

6. Верховна рада України [The Verkhovna Rada of Ukraine]. (1991). Закон України “Про освіту” [Law of Ukraine On Education]. Київ: Офіційне видання Верховної Ради України, с. 451 (in Ukrainian).

7. Всеукраїнська педагогічна рада працівників освіти [All-Ukrainian Pedagogical Council of Educators]. (1996). Концепція національного виховання [The concept of national education]. Київ: Рідна школа, с. 15 (in Ukrainian).

8. Леонгард, Э. (1998). Неслышащие дети в мире слышащих [Deaf children in the world of hearing]. In: Организация службы соичильно-психологической помощи детям с острой школьной дезеадаптацией и их семьям [Organisation of the social and psychological assistance to children with acute school disadaptation and to their families]. Москва, с. 106 (in Russian).

9. Стандартные правила обеспечения равных возможностей для инвалидов [Standard rules for providing equal opportunities for disabled]. (2002). In: Права інвалідів в Україні [Rights of the disabled in Ukraine]. Київ: Сфера, с. 8-9 (in Russian).

10. Таланчук, П., Кольченко, К., Нікуліна, Г. (2004). Супровід навчання студентів 3 особливими потребами в інтегрованому освітньому середовищі [Support of special needs studens' education in the integrated educational environment]. Київ: Соцінформ (in Ukrainian).

11. Чайковський, М. (2006). Сочіально-педагогічні умови реабілітації студентів 3 особливими потребами [Socio-pedagogical conditions of special needs students' rehabilitation]. Doctoral thesis. Вінниця, 210 p. (in Ukrainian). 